\title{
Research on Alternative to Replace Natural Sand in Cement Stabilized Rammed Earth Blocks
}

\author{
Shahrukh Ansari, Vaishali Rajurkar, Anuj Kumar Sharma
}

\begin{abstract}
Natural Sand, which is being used extensively for all types of construction activities, is getting scarce now and many researchers have been put to task of testing other materials like manufactured sand for their usability in civil works. Present study aims at using the locally available soil for producing earth blocks. The materials like Auto aerated clay waste, manufactured sand are used in different proportions to see the possibility as a replacement for natural sand. Both the materials were used in proportion range of $35-65 \%$ along with $8 \%$ cement as a stabilizing agent. The cube compressive strength test was performed on soaked samples after 7 days and 28 days. It has been concluded from the result that the manufactured sand is cheap alternative material to replace natural sand.
\end{abstract}

Key words - Rammed earth blocks, Cube compressive strength, Manufactured Sand, Autoclaved aerated concrete

\section{INTRODUCTION:}

Rammed earth is an ancient construction technique used in many regions of the world. The technology has been gaining renewed attention due to its potential to produce low embodied energy sustainable constructions material. In spite of that the technique can provide better insulation and have tremendous impact on environmental especially in variation of climate and global warming. In this technique red non swelling soil is often use which consists of all the particle range of gravel, sand, silt and the most important is clay content. Optimum clay content leading to maximum strength is in the range of 14-16\%; [7] is preferable. In such technique the soil which may be un stabilized or stabilized where cement is the most commonly used stabilizer to improve strength and weathering resistance of rammed earth. The processed soil is placed in progressive layers in a rigid formwork, which is being removed further. The soil in the formwork is compacted manually to achieve required density of soil. Static compaction appears to be more efficient than dynamic compaction by means of the impact of a falling weight [1]. In this study rammed earth blocks are prepared by dynamic compaction in accordance with IS 4332 Part 5 (Indian Standard 2006b). These type of construction are more preferable for load bearing structures.

Revised Manuscript Received on July 10, 2019.

Shahrukh Ansari, P. G. Student, Department of Civil engineering, Shri Ramdeobaba College of Engineering and Management, Nagpur. India (E-mail: Shahrukh1973@gmail.com)

Prof. Vaishali Rajurkar, Assistant Professor, Department of Civil engineering, Shri Ramdeobaba College of Engineering and Management, Nagpur. India (E-mail: rajurkarvj@rknec.edu)

Dr. Anuj Kumar Sharma, Associate Professor, Department of Civil engineering, Shri Ramdeobaba College of Engineering and Management, Nagpur. India

\section{OBJECTIVE:}

Due to tremendous demand of infrastructural development, there is huge scarcity natural building material such as sand. Some alternative materials have already been used as a replacement of natural sand such as fly-ash, quarry dust, GGBS, Iron slag etc. are used in concrete but very few researchers have studied the effect of such materials in rammed earth construction. On the other side rapid industrialization and modernization produces waste which is not utilized, creates environmental pollution. Reuse of such industrial waste, which may help to achieve effective industrial solid waste management and sustainable development for low cost housing. Efforts are made to Recycling and safe disposal of industrial waste.

The conventional cement based materials are energy intensive requires more energy in their manufacturing and transportation. The cement concrete is one of the primary producers of carbon dioxide, and absorbs heat. Which would results in gradually increasing the earth temperature and increases the operational cost of the building throughout its life? Rammed earth construction is the best alternative which offers an economical and sustainable solution to concrete.

\section{MATERIAL USED IN THE EXPERIMENT:}

Soil: The non-swelling soil samples were collected around Nagpur. The physical properties of the soils are given in Table 1. The soil was tested according to Indian Soil Classification System (IS: 1498, 1970). As red soil is often used in such construction which should be loamy having plasticity property is considerably low. The strength gaining parameter is dry density of soil referring to the study by B.V. Venkatarama Reddy dry density should be within the range of 17 to $18 \mathrm{kN} / \mathrm{m}^{3}$. The important parameter that is swelling characteristics of soil, which should have free swell index less than $10 \%$. The most important is clay content. Optimum clay content leading to maximum strength is in the range of $14-16 \% ;[7]$ is preferable. The various properties of soil is shown in table No.1 
EARTH BLOCKS

\begin{tabular}{|c|c|c|c|c|c|c|}
\hline$\frac{\dot{0}}{0}$ & 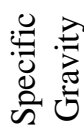 & $\begin{array}{l}\text { Plasticity } \\
\text { properties }\end{array}$ & I.S. & $\begin{array}{c}\text { Gradatio } \\
\mathrm{n}\end{array}$ & $\sum_{0}^{0}$ & 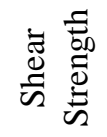 \\
\hline \multirow{3}{*}{$\begin{array}{l}\text { Red } \\
\text { Soil }\end{array}$} & \multirow{3}{*}{2.24} & $\mathrm{WL}=$ & \multirow{3}{*}{ ML } & $\begin{array}{l}\text { Sand - } \\
15.25 \%\end{array}$ & \multirow{3}{*}{$\begin{array}{l}15 . \\
4 \\
\%\end{array}$} & $\begin{array}{l}\mathrm{C}=26 \\
\mathrm{kN} / \mathrm{m}^{2}\end{array}$ \\
\hline & & $\begin{array}{l}\mathrm{W}_{\mathrm{p}}=29.13 \\
\%\end{array}$ & & $\begin{array}{ll}\text { Silt } & -72 \\
\% & \end{array}$ & & \multirow[t]{2}{*}{$\begin{array}{l}\phi \\
14^{\circ}\end{array}$} \\
\hline & & $\mathrm{I}_{\mathrm{p}}=5.87 \%$ & & $\begin{array}{l}\text { Clay- } \\
14.75 \%\end{array}$ & & \\
\hline
\end{tabular}

Table1. Properties of red soil

AAC waste: Autoclaved aerated concrete (AAC) is a lightweight cellular concrete that has been used for more than 80 years. Where large quantity of waste is generated in manufacturing process, which is not being utilized, efforts are made to utilize it in concrete to replace natural sand to improve the thermal properties of the concrete. The aim utilized such waste in place of sand and to improve the thermal performance of earth blocks, AAC waste is obtained from Harmony AAC Buttibori near Nagpur. Currently, no good recycling options for AAC waste exist, therefore it is manually crushed and sieve through $4.75 \mathrm{~mm}$ and retained on 75 micron IS sieve. The specific gravity is found to be 1.87.The dry sieve analysis of crushed waste is made which is found as well graded gradation shown in figure No. 1.

$M$ sand: Manufactured sand is an alternative for river sand. Due to fast growing construction industry, the demand for sand has increased tremendously, causing deficiency of suitable river sand. Since manufactured sand can be crushed from hard granite rocks, it can be readily available at the nearby place, reducing the cost of transportation from far-off river sand bed. Another reason for use of M-Sand is its cost which is ranges from Rs.10 - 15 per cubic feet and river sand price ranges from Rs. 40 - 50 per cubic feet in Nagpur city. M sand is obtained from Nagpur which density is found to be 2.45 and dry sieve analysis and its gradation is shown in figure 2 .

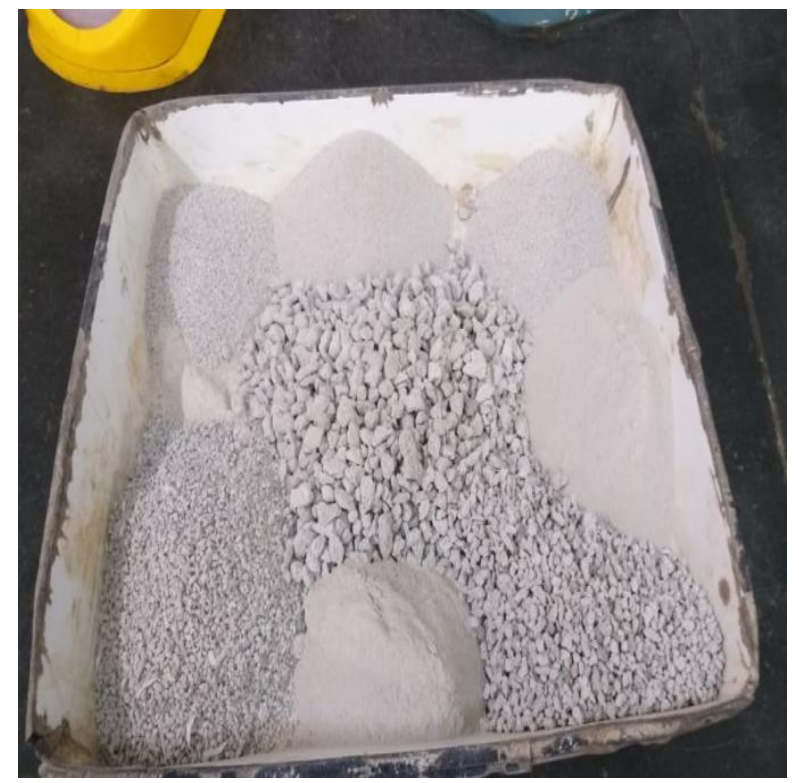

Figure1. Gradation of crushed AAC wastes

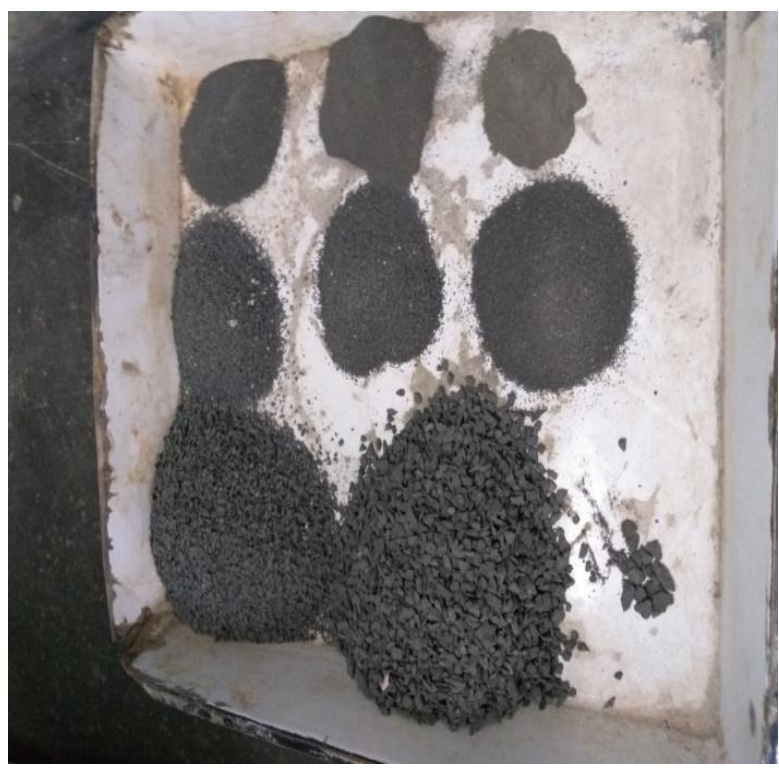

Figure2. Gradation of M sand

\section{EXPERIMENTAL PROGRAM:}

In the present study locally available red soil selected was air dried, pulverized and sieved through $4.75 \mathrm{~mm}$ sieve. The soil is mixed in various combinations with AAC waste and $\mathrm{M}$ sand which replace the natural sand as shown in table No. 2

\begin{tabular}{|c|c|c|c|}
\hline Sample & Red Soil (\%) & M sand (\%) & Stabilizer \\
\hline M-1 & 65 & 35 & Cement \\
\cline { 1 - 3 } M-2 & 55 & 45 & 8\%of total \\
W-3 & 50 & 50 & \multirow{2}{*}{ weight } \\
\cline { 1 - 3 } M-4 & 45 & 55 & \\
\hline M-5 & 40 & 60 & \\
\hline
\end{tabular}

\begin{tabular}{|c|c|c|c|}
\hline Sample & Red Soil (\%) & $\begin{array}{c}\text { AAC Waste } \\
(\mathbf{\%})\end{array}$ & Stabilizer \\
\hline A-1 & 65 & 35 & \\
A-2 & 55 & 45 & \multirow{2}{*}{$\begin{array}{c}\text { Cement } \\
\text { A }\end{array}$} \\
A-3 & 50 & 50 & of total \\
A-4 & 45 & 55 & \multirow{2}{*}{ weight } \\
\hline A-5 & 40 & 60 & \\
\hline
\end{tabular}

Table2. Various mix proportion of sample with soil

The waste which is passed through $4.75 \mathrm{~mm}$ and retained on 75 micron sieve, and washed before use, where the stabilizer such as cement is $8 \%$ shows better results;[7].After the dry mixing of these materials potable water was added slowly as per the optimum moisture content calculated from standard proctor test, the cubes are made by dynamic compaction to achieve required density. After removing the blocks from mould it is cured in wet burlap for 7 and 28 days. Cured samples are immersed in fresh water for $24 \mathrm{hrs}$ and surface dry before testing. The wet cube compressive strength of cubes is carried out in compression testing machine. 


\section{RESULT AND DISCUSSION}

AAC waste is an autoclaved aerated light weight material which density and specific gravity is low due to which in all the combinations of this with soil, dry density of mix is reduces with increasing the percentage of AAC waste. The dry density of AAC waste based blocks is 14.95 to 15.25 $\mathrm{kN} / \mathrm{m}^{3}$. Whereas in the blocks of $M$ sand based blocks dry density is 15 to $20 \%$ more than of AAC based blocks in all the combinations and 30 to $45 \%$ increase in strength than AAC based blocks. The density and specific gravity of $\mathrm{M}$ sand is just equal to natural sand and dry density of blocks is found to be $17.17-17.42 \mathrm{kN} / \mathrm{m}^{3}$, which is quite closure to the recommended values. As per the previous literature dry density greatly affect the strength characteristics of rammed earth blocks, the dry density of such blocks should be 17 to $18 \mathrm{kN} / \mathrm{m}^{3}$, The dry density and wet cube compressive strength is shown in table No.3. As the dry density increases the strength increases.

Table3. Dry density and Wet strength of samples

\begin{tabular}{|c|c|c|c|}
\hline \multicolumn{2}{|c|}{ AAC BLOCK } & \multicolumn{2}{c|}{ M SAND } \\
\hline $\begin{array}{l}\text { Dry density } \\
\left(\mathrm{kN} / \mathrm{m}^{3}\right)\end{array}$ & $\begin{array}{l}\text { Wet } \\
\text { Strength } \\
(\mathrm{MPa})\end{array}$ & $\begin{array}{l}\text { Dry density } \\
\left(\mathrm{kN} / \mathrm{m}^{3}\right)\end{array}$ & $\begin{array}{l}\text { Wet Strength } \\
(\mathrm{MPa})\end{array}$ \\
\cline { 2 - 4 } 15.21 & 1.99 & 17.15 & 2.39 \\
\hline 14.99 & 2.07 & 17.17 & 2.71 \\
\hline 14.85 & 2.19 & 17.18 & 3.17 \\
\hline 14.61 & 2.22 & 17.24 & 4.01 \\
\hline 14.63 & 2.37 & 17.27 & 3.43 \\
\hline
\end{tabular}

In all the combinations of AAC waste wet strength is less as compared to $\mathrm{M}$ sand due to its density as mention above. Increase in $M$ sand increases its density and therefore its cube compressive strength. In all the combinations of mix, strength in $\mathrm{M}$ sand is increases to $20 \%$ to $40 \%$ more than AAC waste as shown in figure 3 . In the samples of $M$ sand cube compressive strength increases with increase in percentage of sand, the maximum strength is found at $55 \%$ sand and $45 \%$ soil. Stress strain curve of $M$ sand is shown in figure 4 .

Further increasing in sand reduces the strength and it is found that mix is become more heterogeneous reduces the bonding between the material. It is also observed that there is increase in strength with curing period around 60 to $70 \%$ increase in strength is observed after 28 days, maximum strength is achieved after 28 days as shown in figure 5.

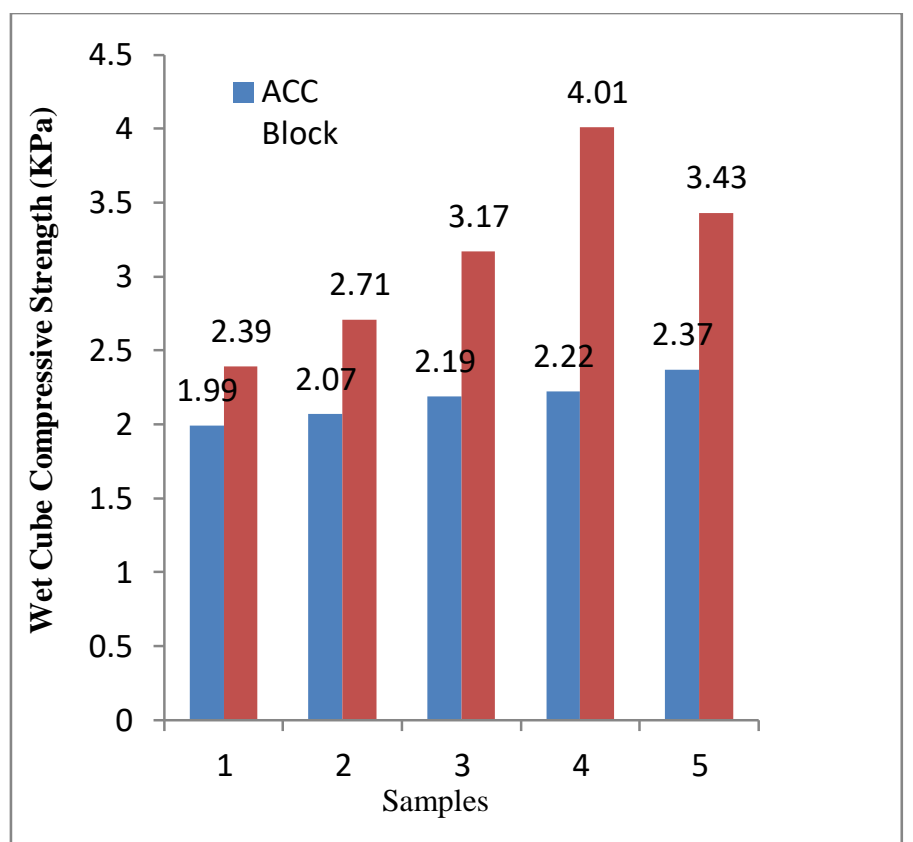

Figure 3.Wet cube compressive strength Comparison of $M$ sand and $\mathrm{AAC}$ waste

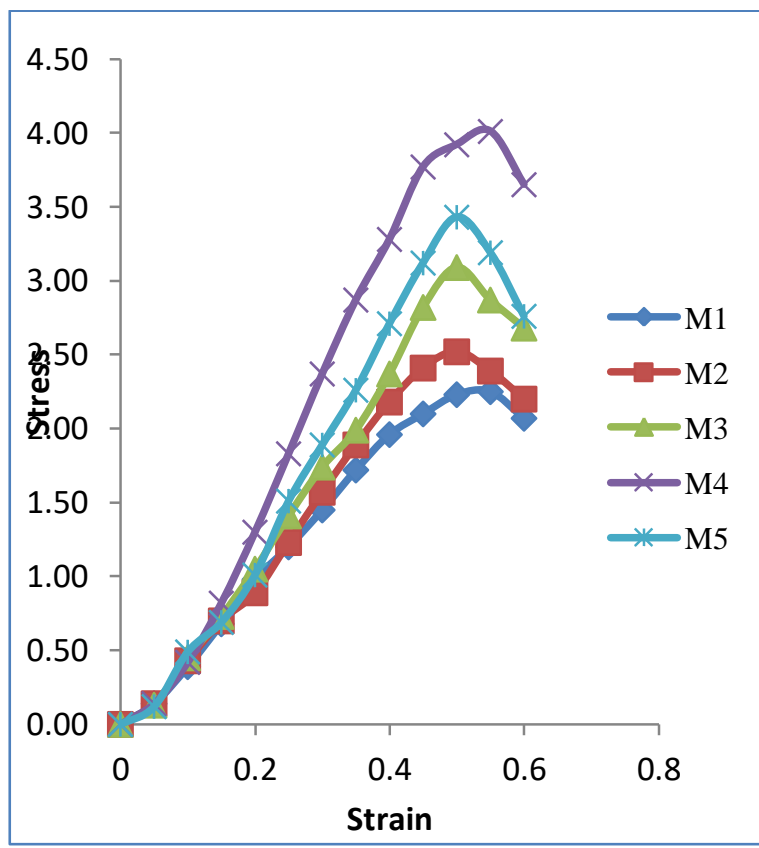

Figure4. Stress strain curve of $M$ sand cube 
EARTH BLOCKS

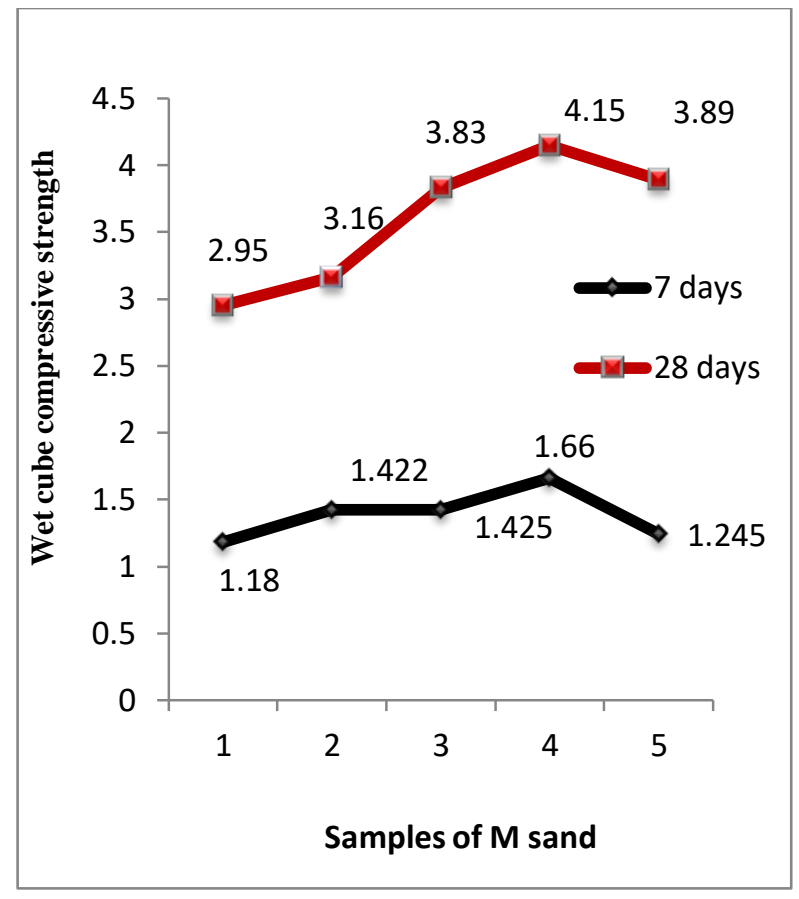

Figure5. Effect of age of curing

\section{CONCLUSION}

Strength properties of RE blocks are significantly affected by its constituents and mixture ratio. The dry density of the rammed earth material is effectively represents their strength behavior. As AAC blocks are considered to be the sustainable building blocks which improved the thermal properties of the concrete but strength of AAC waste is around $40 \%$ less than $\mathrm{M}$ sand in cement stabilized rammed earth blocks, therefore AAC waste cannot be utilized as a replacement of natural sand due to its low density, which reduces the density of mix, and ultimately the strength. M sand is observed to be the best alternative to replace natural sand. Increasing the courser content such as sand and gravel increases the strength of blocks, but more courser materials make the mixture heterogeneous and reduces the strength of blocks. Regarding curing conditions the average characteristics strength of samples after 28 days curing, which is around 60 to $70 \%$ higher than 7 days curing of cubes. Minimum compressive strength requirements above 2.0 $\mathrm{MPa}$ [3] which is achieved 4.67 $\mathrm{MPa}$ after 28 days curing. The $\mathrm{M}$ sand can be effectively used to replace natural sand for the sustainable construction. This can be effectively used for load bearing wall of low rise building.

\section{REFERENCE:}

1. Venkatarama Reddy, Jagadish, et.al. (1993) "The static compaction of soils", Geotechnique 43, No. 2, pp.337-341.

2. Peter Walker, et.al. (1997) "Properties of some cement stabilized compressed earth blocks and mortars", Materials and Structures/Mat4riaux et Constructions, Vol. 30, November 1997, pp 545-551.

3. P. Walker, et.al. (1999) "Bond characteristics of earth block masonry", Journal of Materials in Civil Engineering, Vol. 11, No. 3, ASCE, ISSN 0899-1561/99/0003, pp.0249-0256.

4. Peter J. Walker, (2004) "Strength and Erosion Characteristics of Earth Blocks and Earth Block Masonry", Journal of Materials in Civil Engineering, Vol. 16, No.5, CASCE, pp. 497-506.
5. B. V. Venkatarama Reddy, et.al. (2005) "Characteristics of soil-cement blocks using highly sandy Soils", Materials and Structures 38, pp.651-658.

6. B. V. Venkatarama Reddy, et.al.(2007) “Optimum Soil Grading for the Soil-Cement Blocks" ,Journal of Materials in Civil Engineering, Vol. 19, No. 2, (CASCE, pp.139-148.

7. Steve Burroughs, et.al. (2008), "Soil Property Criteria for Rammed Earth Stabilization", Journal of Materials in Civil Engineering, Vol. 20, No. 3,@ASCE, pp. 264-273.

8. Bingxiang Yuan, et.al. (2011) "A Review of Contemporary Research on Ancient Rammed Earth Technique", Geotechnical Special Publication No. 219 (C) ASCE, pp. 151159.

9. Mihir Vora,et.al. (2014) "Stabilization of Rammed Earth",IJRET: International Journal of Research in Engineering and Technology, Volume: 03 Issue: 04 pp. 298303.

10. H.B. Nagaraja, et.al. (2014) "Role of lime with cement in long-term strength of Compressed Stabilized Earth Blocks", International Journal of Sustainable Built Environment 3, pp.54-61.

11. Deb Dulal Tripura, et.al. (2015) "Characteristic Properties of Cement-Stabilized Rammed Earth Blocks", Journal of Materials in Civil Engineering, (c) ASCE, 08991561/04014214:1-8.

12. B. N. Patowary, et.al. (2015) "Study of Compressed Stabilized Earth Block", International Journal of Scientific and Research Publications, Volume 5, Issue 6, ISSN 22503153, pp.1-4.

13. B. V. Venkatarama Reddy, V. Suresh, et.al. (2016) "B V Characteristic Compressive Strength of Cement-Stabilized Rammed Earth", Journal of Materials in Civil Engineering, () ASCE, ISSN 0899-1561, pp. 04016203:1-7.

14. BUREAU OF INDIAN STANDARDS IS: 2720 (Part 10) 1991 "Indian Standard Methods of Test for Soils", Part 10 Determination of Unconfined Compressive Strength.

15. Designation: D 6276 - 99a "Standard Test Method for using $\mathrm{pH}$ ", Estimate the Soil-Lime Proportion Requirement for Soil Stabilization

16. BUREAU OF INDIAN STANDARDS, IS: 3495-1992 (Part 1 to 4) "Methods of Tests of Burnt Clay Building Bricks", Part 1 Determination of Compressive Strength; Part 2 Determination of Water Absorption. 